
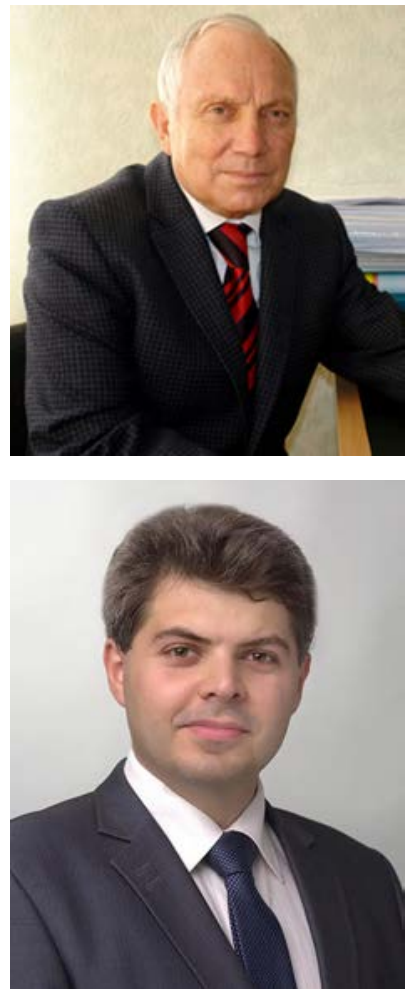

\section{Юрій Кононенко,}

кандичат юричичних наук, Аоцент, завічувач кафредри державно-правових Аисциплін Черкаського національного університету

імені БогАана Хмемьницького

ORCID: 0000-0003-3703-7774

\title{
Сергій Ажолос,
}

каньихат юридичних наук, Аоцент, Аоцент кафредри Аержавно-правових Аисциплін Черкаського національного університету імені БогАана Хмельницького

ORCID: 0000-0002-0001-5523

https://doi.org/10.32782/2306-9082/2021-43-2

\section{Держава і революції. Частина III. Основні ідейно-теоретичні засади революцій Нового часу і сучасності}

Постановка проблеми. У багатьох країнах світу відбуваються нині або нещодавно відбулися революції, повстання, бунти, акції масової непокори і таке інше. Це дає підстави стверджувати, що зміна конституційного ладу й радикальна перебудова існуючих порядків представляється значній частині населення основним способом вирішення всіх суспільних проблем, своєрідною політичною панацеєю. Водночас це створює необхідність здійснити неупереджений аналіз основних ідейних засад революцій Нового часу та сучасності, тобто розкрити їхню сутність та з'ясувати, до яких наслідків вони прагнуть і що саме несуть суспільству: позитивні зрушення чи руйнацію і безлад?

Аналіз досліджень і публікацій. Варто зазначити, що досліджувана проблематика перебувала у полі зору багатьох мислителів давнини та сучасності, насампередтаких, як: Г.Бабьоф, Е. Берк, Дж. Гаррінгтон, Т. Гоббс, Г.Г. Демиденко, К.В. Душенко, Ф. Енгельс, A.I. Кормич, Лао-цзи, В.I. Ленін, Дж. Лілберн, Дж. Локк, Н. Макіавеллі, В.В. Маклаков, А.З. Манфред, Ж.П. Марат, К. Маркс, Дж. Мільтон, В.С. Нерсесянц, О.В. Петришин, К.П. Побєдоносцев, М. Робесп'єр, 
С.Д. Родс, Ж.Ж. Руссо, К. Салмазій, О. Сідней, Б. Спіноза, П.А. Столипін, B.I. Тимошенко, Х. Томазій, Дж. Уінстенлі, Р. Фільмер та інших.

Формулювання цілей статті. Разом із тим деякі аспекти досліджуваної проблематики не знайшли належного відображення й донині, тож у межах цієї статті ми плануємо виявити і порівняти властиві давнині та сучасності ідейно-теоретичні засади, основні суспільно-політичні наслідки, до яких призводять революції, а також висловити думку про загрози спрощеного уявлення про революції давнини та сучасності, вказати на небезпеку недооцінки тих деструктивних наслідків, які вони несуть державі й суспільству.

Виклад основного матеріалу. Неупереджений аналіз революцій давніх часів свідчить, що вони якісно відрізнялися від сучасних революцій своєю інтелектуальною наповненістю та ідейною насиченістю. Наприклад, за часів революційних потрясінь XVII століття в Англії ідеї роялістів були відображені у працях «Патріархія, або Природна влада королів» сера Р. Фільмера, «Королівський захист» К. Салмазія (1649р.), «Філософське начало вчення про громадянина» (1642р.), «Левіафан, або Матерія, форма і влада держави церковної і світської» (1651р.) Т. Гоббса; ідеї індепендентів - у творах «Про владу королів і посадових осіб», «Захист англійського народу проти Салмазія», «Іконоборець» Дж. Мільтона; ідеї левелерів - у працях «Захист природженого права Англії», «Нові кайдани Англії» Дж. Лілберна; ідеї дигерів - у конституційному проекті «Закон свободи» (1652р.) Дж. Уінстенлі; ідеї лібералізму містилися у «Двох трактатах про правління» (1690р.) Дж. Локка. Значний внесок у політичну риторику тих часів зробили також і праці «Міркування про уряд» графа О. Сіднея та «Республіка Океанія» (1656 р.) Дж. Гаррінгтона [1, с. 316-339; 2, c. 79-85].
Загальновідомо, що Французька революція 1789-1799 рр. стала наслідком теоретичних напрацювань Просвітництва XVII - XVIII століть і прагнула утвердження республіки, народного суверенітету, демократії, прав людини, «свободи, рівності, братерства».

Видатний голландський мислитель XVII століття, прихильник теорії природного права і суспільного договору Б. Спіноза (1632-1677) вважав, що природне право - це природна необхідність, яка визначається самою природою або іiї частиною [2, с. 76]. На думку мислителя, найкращою формою держави є демократична, оскільки вона найповнішою мірою відповідає природній свободі особи. Водночас кожен делегує своє природне право не окремій іншій особі, а всьому суспільству, частиною якого він є, що не позбавляє людину права голосу. Демократія, за вченням Б. Спінози, є найкращою формою правління, оскільки вона за своєю природою близька до свободи, якнайкраще забезпечує мир та безпеку народу і сприяє підпорядкуванню всього населення законам. Філософ стверджує, що найраціональнішою формою держави є демократична республіка [2, с. 78], оскільки «в демократичній державі слід менше боятися безглуздостей, адже майже неможливо, щоб більшість зібрання, якщо воно велике, зійшлося на одній безглуздості» [3].

Зі свого боку Ж.Ж. Руссо (1712-1778) на основі ідей суспільного договору розробив теорію народного суверенітету, згідно з якою справедливий суспільний договір має бути укладений на засадах рівності сторін, між рівними суб'єктами, а не між правителями та підданими; за такої умови сутністю цього договору є принцип народного суверенітету [2, с. 104-105]. Мислитель пише, що суспільством слід правити, керуючись виключно загальним благом, і вказує: «Одна тільки загальна воля може управляти силами Держави відповідно до цілі їі утворення, якою 
є загальне благо», водночас «суверенітет ... є лише здійснення загальної волі», a «суверен... є ніщо інше, як колективна істота (яка) може бути представлена тільки сама собою» [4, с. 216]. Ж.Ж. Руссо каже, що народний «суверенітет невідчужуваний, він неподільний, адже воля... є загальною... вона являє собою волю народу як цілого...», за такої умови «накази правителів... можуть вважатися вираженням загальної волі в тому випадку, коли суверен (народ), будучи вільним чинити їм опір, цього не робить. У такому випадку всезагальне мовчання слід вважати знаком згоди народу» [4, с. 217]. На думку Ж.Ж. Руссо, народ-суверен створює закони, але він не зв'язаний із законами назавжди, для народу навіть суспільний договір не є обов'язковим. Народ має право змінити форму правління i навіть розірвати договір та повернути собі природну свободу, звідки логічно випливає право народу на повстання проти тиранії та обгрунтування майбутньої революції [2, с. 104-105]. Зі свого боку Дж. Локк учив, що народ як рівноправна сторона суспільного договору має природне право у будьякий час його розірвати, особливо у випадку, коли влада порушує закони і править неефективно або тиранічно [5, c. 384-405].

Втім філософсько-політичні памфлети витончених мислителів-інтелектуалів - це одне, а звільнений від впливу будь-яких правових та етичних норм натовп вузьколобих санкюлотів, які вбивають, грабують, нищать і палять, - це дещо інше. Тому не слід забувати, що, за влучним висловом Е. Берка, революція - це «жахливий трагікомічний спектакль», «хаос легковажності й люті... (за якого) всі види злочинів змішуються з усіма видами безумств» $[6 ; 7$, с. 71$] \ldots$

«Привид Капіталізму», що «бродив по Свропі» наприкінці XVIII століття, та інтелектуальне надбання Просвітництва насамперед у царині суспільного договору і природного права, знайшли логічне продовження в історичних документах епохи Французької революції 1789-1799 рр., перлиною серед яких прийнято вважати Декларацію прав людини і громадянина від 26 серпня 1789 р., яка проголосила природні та невід'ємні права людини, такі, як рівність, свобода, особиста недоторканість, право власності, право на безпеку та опір гніту, а також ідеї народного суверенітету, рівності перед законом, законності, презумпції невинуватості, рівного доступу до державної служби, підзвітності представників влади народу, свободу поглядів, віросповідання, слова, друку тощо [8, с. 135-137]. Наразі Декларація 1789 р. є складником Конституції Франції 1958 р. [8, с. 94-96], iï ідеї відіграли вагому роль у контексті формування та розвитку каталогу прав людини.

Загалом політична думка часів Французької революції 1789-1799 рр. та Наполеона I (1799-1815 рр.) була вельми плідною: досить згадати проєкти ебертистів, жирондистів, кордельєрів, монтаньярів, «скажених», фельянів, якобінців та безлічі інших політичних клубів часів революції, серед яких найвідоміші такі праці, як «Проєкт декларації прав людини і громадянина 3 наступним планом справедливої, мудрої та вільної Конституції» Ж.П. Марата (1789р.), доповіді та промови М. Робесп'єра «Про принципи революційного уряду», «Про принципи політичної моралі», «Про конституцію» (1793-1794рp.), «Маніфест плебеїв» (1795р.), документи й матеріали «Заколоту в ім'я рівності» Г. Бабьофа середини 1790-х рр. [2, с. 105-107], а також 8 конституцій Франції тієї буремної епохи - конституції 1791 р., I року (1793р.), III року (1795 р.), VIII року (1799 р.), X року (1802 р.), XII року (1804р.), Хартія 1814 р. Людовіка XVIII, наполеонівський «Додатковий акт до конституцій Імперії» періоду «Ста днів» 1815 р. 
Втім Лао-цзи ще у VI столітті до н.е. небезпідставно стверджував: «Коли множаться закони й укази, зростають розбої та грабежі» $[9$, с. 281$] \ldots$

Безперечно, багато сучасників-французів могли би пишатися величчю своєї епохи, оцінити правозахисні документи й державотворчий потенціал якобінців та інших угруповань часів Французької революції, якби тільки заклинило гільйотину...

Водночас видатний науковець, спеціаліст з історії Франції А.З. Манфред так описав значення Французької революції: «На порядок денний було поставлено перехід від феодалізму до капіталізму... Французька революція XVIII століття за своїм характером, за своїми рушійними силами була, безсумнівно, народною революцією, буржуазно-демократичною, і саме вирішальна роль народу у цій революції і надала їй такої сили та розмаху, підняла іï над іншими буржуазними революціями, надала їй ті класичні риси, які дозволили називати їі Великою французькою революцією» [10, с. 216].

Тож Велика Французька революція 1789-1799 рр., хоч і ціною величезних втрат, призвела до формування у майбутньому сучасного буржуазного політико-правового та соціально-економічного ладу Європи, який продемонстрував свою достатню ефективність в епоху імперіалізму XIX ст. та неоколоніалізму XX-XXI ст. принаймні для західноєвропейських народів (за рахунок інших). Тобто проголошення формальної рівності та свободи дало змогу європейським країнам зменшити рівень соціальної напруги і скерувати агресію й намагання злиденних мас швидко збагатитися за чужий рахунок із внутрішнього напрямку (боротьба третього стану проти панування феодалів) на зовнішній - загарбання і грабіж колоній, що загалом сприяло збагаченню Європи. Із цього приводу В.І. Ленін у роботі «Імперіалізм, як вища стадія капіталізму
(Популярний нарис)» указує, що на рубежі XIX - XX ст. відбувся перехід провідних європейських держав від епохи первісного накопичення капіталу до стадії монополістичного капіталізму чи імперіалізму, який, за висловом британського колонізатора С.Д. Родса, є порятунком від громадянської війни [11, с. 299-426].

Зокрема, у 1895 р. С.Д. Родс казав: «...Моєю заповітною ідеєю є вирішення соціального питання, а саме: щоб урятувати сорок мільйонів мешканців Об'єднаного Королівства від вбивчої громадянської війни, ми, колоніальні політики, повинні заволодіти новими землями для розміщення надлишку населення для набуття нових областей збуту товарів, що виробляються на фабриках і в рудниках. Імперія, я завжди говорив це, є питанням шлунка. Якщо ви не хочете громадянської війни, ви повинні стати імперіалістами» [11, с. 376].

Зауважимо, що у цьому плані, починаючи з 1895 р., мало що змінилося, хіба що істотно зросла чисельність населення Британії зокрема й за рахунок люмпенізованих мігрантів; на фабриках стало вироблятися ще більше товарів, що підлягають збуту у колоніях; та й окрім «Старушки-Англії» наведені вище ідеї взяли на озброєння деякі інші країни, зокрема й англосаксонські...

У свою чергу Жовтнева революція 1917 р. стала результатом теоретичних напрацювань таких відомих мислителів, як К. Маркс, Ф. Енгельс та B.I. Ленін, які прагнули побудови ідеального комуністичного суспільства.

B.I. Ленін у своїй відомій праці «Держава та революція. Вчення марксизму про державу та завдання пролетаріату в революції», написаній у серпні-вересні 1917 р., описує сучасний контекст як імперіалізм, за якого світ поділено між «великими грабіжницькими державами» [12, с. 11]. Зокрема, він розглядає державу як «орган 
класового панування» або «організацію насильства», котра має відумерти внаслідок настання комунізму, та вказує, що «Тільки в комуністичному суспільстві, коли опір капіталістів уже остаточно придушено, коли капіталісти зникли, коли нема класів (тобто нема відмінностей між членами суспільства за їхнім відношенням до суспільних засобів виробництва), - тільки тоді «зникне держава і можна говорити про свободу». Тільки тоді можлива та буде втілена демократія дійсно повна, дійсно без всіляких винятків. I тільки тоді демократія почне відмирати внаслідок тієї простої обставини, що, врятовані від капіталістичного рабства, від незліченних жахів, дикості, безглуздостей, мерзенностей капіталістичної експлуатації, люди поступово звикнуть до елементарних, століттями відомих, тисячоліттями повторюваних у всіх приписах правил співжиття, до дотримання їх без насильства, примусу, підкорення, без особливого апарату для примусу, який називається державою» [12, с. 89].

Цитуючи К. Макса, В.І. Ленін продовжує: «На вищій фазі комуністичного суспільства, після того, як зникне підкорення людини поділу праці, що пригноблює iㅣ, та коли зникне разом із цим протилежність розумової і фізичної праці, коли праця перестане бути лише засобом для життя, а стане сама першою потребою життя; коли разом із всебічним розвитком індивідуумів зростуть і виробничі сили та всі джерела суспільного багатства поллються повним потоком, - лише тоді можна буде зовсім подолати вузький горизонт буржуазного права, і суспільство зможе написати на своєму прапорі: «Від кожного - за здібностями, кожному - за потребами» [12, с. 95].

К. Маркс і Ф. Енгельс у своїй відомій праці «Маніфест Комуністичної партії» (1848р.) закликають до побудови ідеального безкласового комуністичного суспільства зі суспільною власністю на засоби виробництва та зазначають, що «Історія всіх суспільств, що існували донині, була історією боротьби класів. Вільний і раб, патрицій і плебей, поміщик і кріпак, майстер і підмайстер, коротше, гнобитель і пригноблений перебували в одвічному антагонізмі один до одного, вели безперервну, то приховану, то явну боротьбу, яка завжди закінчувалася революційною перебудовою всієї суспільної будови або спільною загибеллю ворогуючих класів» [13, с. 424].

Отже, класики марксизму прямо вказують, що революція може закінчитися не тільки досягненням бажаного результату, але й повним знищенням суспільства. Разом із тим у названій праці К. Маркс і Ф. Енгельс фактично закликають ризикнути знищенням існуючих порядків в ім'я високих програмних цілей, частина яких не втратила своєї актуальності й понині (та навіть сприяла формуванню справжньої соціальної держави у деяких країнах Заходу і зростанню могутності Китаю), таких як: «1) експропріація земельної власності та використання земельної ренти для покриття державних витрат; 2) високий і прогресивний податок; 3) скасування права спадкування; 4) конфіскація майна всіх емігрантів і бунтівників; 5) централізація кредиту в руках держави за допомогою національного банку 3 державним капіталом та 3 виключною монополією; 6) централізація всього транспорту в руках держави; 7) збільшення кількості державних фабрик, засобів виробництва, розчищення під оранку та покращення земель за загальним планом; 8) однакова обов'язковість праці для всіх, заснування промислових армій, особливо для землеробства; 9) поєднання землеробства із промисловістю, сприяння поступовому усуненню відмінностей між містом і селом. 10) суспільне та безкоштовне виховання всіх дітей, усунення фабричної праці дітей у 
сучасній формі, поєднання виховання 3 матеріальним виробництвом тощо» [13, c. 446-447].

Тож кожна із давніх революцій (Англійська, Французька, Російська), фактично призвела до істотних зрушень, пов'язаних із переходом від однієї суспільно-економічної формації до іншої: унаслідок подій $1640-x$ рр. в Англії і 1789-1799 рр. у Франції відбувся перехід від феодалізму до капіталізму, а внаслідок подій 1917 р. у Росії від капіталізму до соціалізму. Тож давні революції, які втопили у крові свої народи, грунтувалися на певних прогресивних, хоча й утопічних, ідеях, які люди підтримували та жертвували собою в ім'я «світлого майбутнього». Основу цього «майбутнього» зазвичай складали обумовлені часом позитивні зрушення щодо розвитку прав і свобод людини, підвищення добробуту й рівня життя суспільства. У зв'язку з цим відсутні підстави стверджувати, що Старий режим себе вичерпав, і його трансформація у прогресивному напрямку була неможлива без революції.

Натомість, на відміну від давніх, сучасні революції фактично не пропонують нічого нового та характеризуються ідейною схематичністю і примітивізмом. Основні їхні прагнення спрямовані на зміну зовнішньополітичного вектора, повалення «поганої» старої влади та забезпечення приходу «хорошої» нової. Зокрема, звичайно, не йдеться про наявність філософського чи політико-правового підгрунтя у сучасних революцій. Більше того, вони не мають змістовних програмних документів, цілісного плану реформ, механізму забезпечення добробуту суспільства, тобто в сучасних революціонерів відсутнє чітке уявлення про майбутні риси держави, порядок здійснення державного управління і шляхи здолання негативних явищ, які спричинили революцію.

Отже, всі ідейні засади сучасних революцій зводяться до пафосних промов популістського характеру, що виголошуються їхніми лідерами, які, насправді, нездатні ані до теоретичної, ані до практичної діяльності. Це й не дивно, адже видатний юрист і державний діяч К.П. Побєдоносцев (1827-1907) ще наприкінці XIX століття застерігав, що «маса населення, покликана до розробки програми державного управління, не здатна до широких узагальнень теоретичного характеру, що грунтуються на вивченні фактів та явищ життя, i, будучи безсилою у справі законодавства й управління, підкоряється вождям, здатним красиво говорити, захоплювати натовп, а часом і підтасовувати думку й волю народу. Звідси зрозуміла й загроза» [14, с. 2436].

У контексті найпопулярніших революційних ідей сучасності - зміни зовнішньополітичного вектора та повалення «поганого» старого правителя для передання влади «хорошому» новому, - зазначимо, що сучасними революціонерами не беруться до уваги очевидні факти. По-перше, якісне покращення ситуації у країні аж ніяк не $є$ гарантованим наслідком зміни зовнішньополітичного вектора. У кращому разі це призводить до укладення певної міжнародної угоди, яка не заважає жодній зі сторін денонсувати іiі у майбутньому, тим більше, що примарна надія на міжнародні судові установи залежить від наявності чи відсутності добровільного визнання їхньої юрисдикції сторонами договору. Водночас норми міжнародного права, крім незначної кількості норм jus cogens (які, до речі, й так поширюються на всіх членів міжнародного співтовариства незалежно від їхньої згоди), за своєю природою мають диспозитивний характер, тобто виконують скоріше регулятивну, ніж охоронну функцію. По-друге, інтереси «іноземних партнерів» часто можуть прямо суперечити національним інтересам батьківщини революціонерів, процвітання 
якої залежить насамперед від стабільного розвитку, що є несумісним із революційними потрясіннями.

...Доволі утопічною виглядає також ідея повалення чинного «поганого» правителя в надії на те, що наступний буде «хорошим». Зокрема, 3-поміж сучасних людей мало хто замислюється над тим, що ми живемо не за часів спадкової абсолютної монархії, тож, по-перше, панування нового «хорошого» правителя встановлюватиметься лише до чергових виборів, тобто на кілька років, упродовж яких державі ще треба подолати наслідки революційних потрясінь і вийти хоча б на дореволюційний рівень розвитку; по-друге, в умовах поділу влади глава держави не є самодержцем та не має всієї повноти влади, а тим більше - чарівної палички чи рогу достатку; по-третє, за умови існування складного й розгалуженого апарату держави, що містить сотні тисяч чиновників різних рівнів, одного лише «доброго царя» явно не досить для того, щоб забезпечити благоденство в усій країні. До того ж очевидно, що гіпотетичні прогресивні реформи неодмінно наштовхнуться на запеклий опір клептократії, тож за жодних обставин новий «хороший» демократичний правитель не зможе правити довго та ефективно. Отже, будь-яка революція апріорі не може бути панацеєю для розв’язання життєво важливих і суспільно значимих політико-правових проблем.

Варто наголосити той факт, що повалення «поганої» влади й утвердження «хорошої»- це зовсім не те ж саме. До того ж кожна людина, громадські об'єднання та їхні лідери повинні замислюватися над тим, чи не використовуються їхні благі наміри представниками олігархічно-політичних угруповань у боротьбі за владу...

Геніальний італійський мислитель епохи Відродження Н. Макіавеллі вчив: «Люди, віруючи, що новий правитель виявиться кращим, охоче повстають проти старого, але скоро на власному досвіді переконуються, що помилилися, оскільки новий правитель завжди виявляється гіршим за старого. Що знову ж таки природно й закономірно, оскільки завойовник пригноблює нових підданих, накладає на них різного роду повинності та обтяжує їх постоями війська, як це неминуче буває під час завоювання. Отже, він наживає собі ворогів серед тих, кого пригнобив, і втрачає дружбу тих, хто допомагав завоюванню, бо не може винагородити їх тією мірою, яку вони очікували, але й не може застосувати до них круті заходи, будучи їм зобов'язаним, - адже без їхньої допомоги він не міг би увійти до країни, яким би сильним не було його військо» [15, с. 35].

Отже, цілком очевидним стає той факт, що зазвичай революція - це лише протизаконний, хоча й універсальний, інструмент переходу влади від одних клептократів до інших, який відбувається ціною колосальних втрат. Інакше кажучи, революція - це політична авантюра, тобто за означенням «ризикована й сумнівна справа, здійснена 3 надією на випадковий успіх» [16, с. 16]. Зокрема, статистичні дані Світового банку переконливо свідчать, що омріяний «успіх» практично ніколи не досягається після революціï. Наприклад, у 2013 р. ВВП України становив 183,31 млрд. доларів США, у 2014 р. він знизився до 133,5 млрд. доларів США, у 2015-2016 рр. він упав до абсолютного мінімуму - 91,03 93,36 млрд. доларів США (вдвічі менше, ніж у 2013 р.), у 2019 р. він досягнув показника 153,78 млрд. доларів США, у 2021 р. за прогнозами він ледь перетне позначку у 160 млрд. доларів США, тобто нині, на 8-й рік після початку Революції гідності, Україна так і не досягла рівня 2013 р. [17].

Утім події 2005 р. у Кліші-суБуа (Франція) [18], 2011 р. - у Тоттенхемі (Велика Британія) [19], 2013 р. - у Хусбю (Швеція) [20], 2020 р. - у м. Міннеаполіс (США) 
[21] та інші переконливо свідчать, що доволі часто, навіть у розвинутих країнах, заворушення виникають спонтанно. Поштовхом до них можуть бути навіть законні дії працівників правоохоронних органів щодо правопорушників, які чинять опір (зокрема і збройний).

Т. Гоббс учить, що люди укладають суспільний договір та передають свої права і свободи державі для того, щоб вона, маючи велику владу, могла забезпечити мир у суспільстві, гарантувати людині життя і безпеку та спрямувати iㅣ дії на досягнення загального блага [22; 23]. Отже, зауважимо, що насильство, правомірно застосоване працівниками правоохоронних органів до правопорушників, повинно не засуджуватися, а схвалюватися, оскільки воно необхідне для захисту суспільства від протиправних посягань i виконання державою своїх прямих обов’язків перед людьми, що випливають із суспільного договору. Так само суспільством має схвалюватися й насильство, правомірно застосоване правоохоронними органами щодо мітингувальників, оскільки від перекриття доріг, хуліганства, погромів, підпалів, грабежів та інших правопорушень, що вчиняються під час масових заворушень, страждають насамперед звичайні законослухняні громадяни, а не органи влади та посадові особи, чиї дії не влаштовують мітингувальників.

Отже, головною рушійною силою заворушень, подібних до згаданих вище, є маргінальна частина суспільства, налаштована на вчинення деструктивних дій, яка вважає, що навіть «держава - нічний сторож» $€$ втіленням деспотизму, душителем свободи та гнобителем прав людини.

Разом із тим ще наприкінці XVIII ст. Е. Берк писав, що революціонери «закладають міну, яка разом підірве всі давні зразки, всі звичаї, хартії, парламентські акти. Ця міна - права людини...» [6; 7, с. 130]. Мислитель продовжує: «Теоретичні права людини входять до повсякденного життя подібно променю світла, що проходить крізь густе середовище по прямій і за законами природи відбивається під кутом. Дійсно, у величезній масі пристрастей та інтересів права людини зазнають такого різноманіття заломлень та віддзеркалень, що теоретичні спори про них стають абсурдом. Людська природа складна і заплутана, суспільні інтереси теж надзвичайно складні, отже, немає такого політичного напрямку, немає такої влади, яка влаштовувала би кожного» [6; 7, с. 134].

Отже, «Права, про які кажуть теоретики, - це крайність; тією мірою, якою вони метафізично правильні, вони фальшиві 3 погляду на політику й мораль. ... Теоретики завжди софістично змішують права людей із їхніми можливостями; допоки можливості та права - те ж саме, вони разом несумісні 3 доброчесністю і з першою з чеснот розсудливістю. Люди не мають права на те, що не розсудливо і не є для них благом... Ці професори, зрозумівши, що їхні крайні принципи і політичні схеми неможливо застосувати до стану світу (миру), в якому вони живуть... постійно прагнуть до змін державного ладу... Вони надають своїм розумовим проєктам величезної цінності та, не поважаючи існуючий державний лад, байдуже ставляться до можливості його вдосконалення. Вони не бачать шкоди у поганому управлінні справами суспільства, навпаки, вони вважають, що ці вади створюють сприятливі умови для революціiі» [6; 7, с. 135-138].

Е. Берк наголошує, що «уряд створюється не для захисту природних прав людини, які можуть існувати та існують незалежно від нього, зберігаючи свою вищою мірою абстрактну досконалість; але ця абстрактна досконалість - їх практичний недолік. Маючи право на все, люди хочуть отримати все. Держава - це мудрий винахід людства, призначений для 
забезпечення людських бажань. Люди мають право на те, щоб ця мудрість була спрямована на задоволення їхніх потреб. Але держава вимагає, щоб вони стримували свої пристрасті й бажання. Суспільство вимагає не тільки обмеження потреб індивідів, але щоб і в масі посягання людей присікалися, їхня воля управлялась, а пристрасті стримувалися. Все це можливо тільки за наявності Влади, що стоїть поза ними, котра під час виконання своїх функцій не піддаватиметься тим самим пристрастям і бажанням, які сама зобов'язана придушувати й підкорювати. У цьому сенсі обмеження, так само, як і свобода, повинно бути включене до прав людини» [6; 7, с. 132-133].

Звідси випливає той факт, що важливою засадою співжиття людей в умовах цивілізованого суспільства є позитивна дискримінація, тобто певне обмеження прав і свобод людини, необхідне для недопущення заподіяння суттєвої шкоди її істинним потребам та інтересам.

Класичним прикладом позитивної дискримінації, яка існує впродовж останніх років, слід уважати запровадження урядами багатьох держав певних карантинних заходів, пов'язаних iз обмеженням свободи пересування та деяких інших прав людини в умовах пандемії коронавірусу. Водночас це призвело до поширення антикарантинних коронавірусних заворушень та акцій непокори (сучасного аналогу старовинних, холерних, бунтів): народ не вірить в існування коронавірусу, прагне «хліба та видовищ», «бенкету під час чуми», не хоче носити маску й мити руки.

У цьому контексті не можна не згадати позицію видатного німецького мислителя епохи бароко Х. Томазія (1655-1728), який учив, що мораль подібна до поради учителя та забезпечується переконанням, натомість право - це настанова правителя, яка забезпечується примусом [2, с. 108]; для мудрих людей досить поради, тоді як для дурних необхідний примус, тож державна влада рятує людей від страху перед шкодою, яку можуть заподіяти дурні [24, с. 87].

Зі свого боку Б. Спіноза стверджував, що держава вчиняє злочин, коли робить або терпить те, що може бути причиною iï загибелі. Держава для того, щоб бути повноправною, зобов'язана зберігати основи поваги i страху, у протилежному випадку вона перестає бути державою [2, с. 78].

Крім того, варто зазначити, що те, що нині прийнято називати «революціями», насправді не є ними, оскільки не відповідає класичним ознакам революції: так звані сучасні «революції» не призводять до глибоких якісних перетворень, переходу від однієі суспільно-економічної формації до іншої, до зміни соціально-економічної моделі, форми власності, виробничих відносин, способу отримання і форм винагороди за працю, кардинальних глибоких змін панівного політичного режиму, політичної системи, відносин, інститутів, цінностей, ідеології, свідомості, культури тощо. Більше того, зауважимо, що, відкидаючи ідеї К. Маркса та Ф. Енгельса щодо побудови соціалістичного і комуністичного суспільства та разом із ними - й сам формаційний підхід, нині ніхто навіть і не скаже, якою ж має бути наступна суспільно-економічна формація, до чого повинна прагнути сучасна революційна ідея. Тож інтелектуальна люмпенізація широких мас та ідейний вакуум, притаманні сучасним революціям, дають підстави стверджувати, що на відміну від давніх революцій, вони апріорі не можуть призвести до прогресивних зрушень та позитивних наслідків, адже не мають жодних грунтовних теоретичних підвалин і практичної здатності покращити стан справ у суспільстві, отже, є виявом виключно деструктивного начала.

На останок слід згадати крилаті слова видатного державного діяча 
П.А. Столипіна: «Супротивникам державності хотілося б обрати шлях радикалізму... Їм потрібні великі потрясіння, а нам потрібна Велика Держава!» $[25$, с. 40$]$.

Отже, внаслідок проведеного дослідження ми дійшли таких висновків:

1) давні революції зазвичай мали вельми грунтовні філософські підвалини і політичні програми. Зокрема, філософсько-політичне осмислення революційних подій в Англії XVII століття знайшло відображення у програмах роялістів, індепендентів, левелерів, дигерів, творах Т. Гоббса i Дж. Локка та інших. Французька революція 1789-1799 рр. стала наслідком теоретичних напрацювань мислителів XVII - XVIII століть і прагнула утвердження республіки, народного суверенітету, демократії, прав людини та «свободи, рівності, братерства». Ї̈і ідеї відображено не тільки у творах Просвітників, але й у програмних документах, доповідях і промовах революціонерів та історичних документах на кшталт Декларації прав людини і громадянина 1789 р. та перших 8 французьких конституцій. Отже, Французька революція 1789-1799 рр., хоч i ціною величезних втрат, але призвела до формування в далекому майбутньому сучасного буржуазного ладу Європи, який загалом продемонстрував свою достатню ефективність в епоху імперіалізму XIX ст. та неоколоніалізму XX - XXI ст. принаймні для західноєвропейських народів (за рахунок інших). Тобто ідеї «свободи, рівності, братерства» дали змогу європейським країнам згуртувати суспільство, зменшити рівень соціальної напруги і скерувати агресію й намагання люмпенізованих мас швидко збагатитися за чужий рахунок із внутрішнього напрямку (боротьба проти феодалів) на зовнішній - загарбання та грабіж колоній, що сприяло збагаченню Європи.

У свою чергу Жовтнева революція 1917 р. ціною величезних втрат сприяла своєрідному втіленню соціалістичних ідей К. Маркса, Ф. Енгельса, B.I. Леніна та перетворенню однієї великої держави (Російська імперія) на другу (СРСР). Більше того, соціалістичні ідеї сприяли зростанню могутності Китаю та побудові соціальної держави в деяких країнах Заходу.

Тож кожна 3 цих революцій (Англійська, Французька, Російська) фактично призвела до істотних зрушень, пов'язаних із переходом від однієї суспільно-економічної формації до іншої: унаслідок подій 1640-х рр. в Англії і 1789-1799 рр. у Франції відбувся перехід від феодалізму до капіталізму, а внаслідок подій 1917 р. у Росії - від капіталізму до соціалізму. Втім це зовсім не означає, що Старий режим себе вичерпав та існувала нагальна потреба в революції;

2) на відміну від давніх, сучасні революції фактично не пропонують нічого нового та характеризуються ідейною схематичністю і примітивізмом. Зазвичай не йдеться про істотне філософське чи теоретичне підгрунтя сучасних революцій, наявність більшменш серйозних програмних документів, існування цілісного плану політичних і соціальних реформ. Більше того, у лідерів сучасних революцій відсутнє чітке уявлення про майбутні риси держави, порядок здійснення державного управління і шляхи подолання негативних явищ, які спричинили революцію. Ідеологічною основою сучасних революцій зазвичай є дві ідеї. Перша ідея - це зміна зовнішньополітичного вектора держави. Прихильники революції чомусь забувають, що, враховуючи специфіку міжнародного права, будь-який міжнародний договір, укладений за підсумками революції, може бути легко денонсований. Окрім того, інтереси «іноземних партнерів» можуть суперечити національним інтересам батьківщини революціонерів, процвітання якої залежить насамперед від стабільного розвитку, який є несумісним 
iз радикальними революційними потрясіннями. Друга ідея полягає в бажанні повалити «поганого» старого правителя задля того, щоб наділити владою «хорошого» нового. Водночас прихильники революції забувають про те, що в умовах республіки нова влада у кращому разі буде встановлена лише на кілька років, до чергових виборів, а також про те, що в умовах поділу влади та існування розгалуженого апарату держави, що містить сотні тисяч чиновників усіх рівнів, одного лише «доброго» нового правителя явно не досить для того, щоб забезпечити процвітання всієї країни. До того ж гіпотетичні прогресивні реформи неодмінно наштовхнуться на запеклий опір клептократії, тож за жодних обставин новий «хороший» демократичний правитель не зможе правити довго та ефективно. Отже, революція апріорі не може бути панацеєю для розв'язання життєво важливих і суспільно значимих політико-правових проблем;

3) повалення «поганої» старої влади зовсім не тотожне утвердженню «хорошої» нової, тож революційним масам слід замислюватися над тим, чи не використовуються їхні благі наміри представниками олігархічно-політичних угруповань у боротьбі за владу задля задоволення своїх егоїстичних інтересів всупереч потребам суспільства. Отже, будь-яка революція - це політична авантюра, тобто за означенням «ризикована та сумнівна справа, здійснена 3 надією на випадковий успіх». Водночас від масових заворушень, перекривання доріг, хуліганства, погромів, підпалів і грабежів страждають насамперед звичайні законослухняні громадяни, а не посадові особи та органи влади, чия діяльність спричинила невдоволення мітингувальників;
4) те, що нині прийнято називати «революціями», насправді не є ними, оскільки не відповідають класичним ознакам революції: так звані «революції» сучасності не призводять до глибоких якісних перетворень, переходу від однієї суспільно-економічної формації до іншої, до зміни соціально-економічної моделі, форми власності, виробничих відносин, способу отримання та форм винагороди за працю, кардинальних глибоких змін панівного політичного режиму, політичної системи, відносин, інститутів, цінностей, ідеології, свідомості, культури. Наголосимо, що внаслідок сучасних революцій у кращому разі на місце одних клептократів приходять інші, а в гіршому - відбувається тотальна руйнація країни і знищення суспільства, як у Лівії чи Сирії. Зауважимо, що відкидаючи соціалістичні ідеї К. Маркса та Ф. Енгельса й разом із ними - сам формаційний підхід, нині немає будьяких вагомих теоретичних досліджень наступної суспільно-економічної формації і того, до чого повинна прагнути революційна ідея. Водночас ідейний вакуум, притаманний сучасним революціям, дає підстави стверджувати, що на відміну від давніх, вони апріорі не можуть призвести до прогресивних зрушень і позитивних наслідків, адже не мають жодних грунтовних теоретичних підвалин і практичної здатності вирішити проблеми суспільства.

Перспективними напрямами подальшого розроблення цієї проблематики вбачаємо розкриття сутності кольорових революцій сучасності як загрози державності, виявлення основних засад діяльності сучасної держави 3 попередження революцій та їхніх деструктивних наслідків, що і планується зробити надалі.

\section{Список використаних джерел}

1. История политических и правовых учений: Учебник для вузов. Под общ. ред. акад. РАН, д.ю.Н., проф. В.С. Нерсесянца. 4-е изд., перераб. и доп. Москва: Норма, 2006. 944 с. 
2. Історія вчень про державу і право: підручник. За ред. проф. Г.Г. Демиденка, проф. О.В. Петришина. Харків: Право, 2009. 256 с.

3. Спиноза Б. Богословско-политический трактат. Перевод с латинского М.М. Лопаткина, С.М. Роговина, Б.В. Чредина. Москва: Академический проект, 2015. 486 с.

4. Руссо Ж.Ж. Об общественном договоре. Трактаты. Перевод с французького. Москва: Канон-пресс-Ц, Кучково поле, 1998. 416 с.

5. Локк Дж. Сочинения: в 3 т. Москва: Мысль, 1988. Т. 3. 623 с.

6. Берк Э. Размышления о революции во Франции и заседаниях некоторых обществ в Лондоне, относящихся к этому событию. Сокращенный перевод с английского Е.И. Гельфанд. Москва: Рудомино, 1993. 144 с.

7. Берк Э. Размышления о революции во Франции и о прениях в некоторых лондонских обществах касательно сего события, содержащиеся в письме, предполагавшемся быть отправленным некоему благородному господину в Париж. Пер. с англ. С. Векслер. Под ред. А. Бабича. London: Overseas Publications Interchange Ltd, 1992. 411 c.

8. Конституции зарубежных государств. Учебное пособие. 2-е издание, исправленное и дополненное. Составитель В.В. Маклаков. Москва: Издательство БЕК, 1997. 586 с.

9. Душенко К.В. Большая книга афоризмов. Издание 6-е, исправленное. Москва: Издательство ЭКСМО-Пресс, 2002. 1056 с.

10. Манфред А.З. Великая французская революция. Москва: Наука, 1983. 432 с.

11. Ленин В.И. Империализм, как высшая стадия капитализма (Популярный очерк). Полное собрание сочинений: в 55 т. Издание пятое. Москва: Издательство политической литературы, 1969. Т. 27: август 1915 - июнь 1916. С. 299-426.

12. Ленин В.И. Государство и революция. Учение марксизма о государстве и задачи пролетариата в революции. Полное собрание сочинений: в 55 т. Издание пятое. Москва: Издательство политической литературы, 1969. Т. 33: Государство и революция. С. 1-120.

13. Маркс К., Энгельс Ф. Манифест Коммунистической партии. Сочинения: в 39 т. Издание второе. Москва: Государственное издательство политической литературы, 1995. Т. 4. С. 419-459.

14. Побъдоносцевъ Константинъ Петровичъ. Полный православный богословскій энциклопедическій словарь: в 2 т. Санктъ-Петербургъ: Издательство П.П. Сойкина, 1913. Т. 2. С. 2434-2439.

15. Макиавелли Н. Государь; Рассуждения о первой декаде Тита Ливия. Санкт-Петербург: Азбука-классика, 2008. 272 с.

16. Ожегов С.И., Шведова Н.Ю. Толковый словарь русского языка: 80000 слов и фразеологических выражений. Российская академия наук. Институт русского языка им. В.В. Виноградова. 4-е изд., дополненное. Москва: ООО «А ТЕМП», 2006. 944 с.

17. Ukraine GDP. Trading Economics. URL: https://tradingeconomics.com/ukraine/ gdp (date of reference 16.06.2021).

18. Массовые беспорядки во Франции (2005). Википедия - свободная энциклопедия. URL: https://ru.wikipedia.org/wiki/Массовые_беспорядки_во_Франции_(2005) (дата обращения 14.01.2021).

19. Беспорядки в Англии в августе 2011 года. Википедия - свободная энциклопедия. URL: https://ru.wikipedia.org/wiki/Беспорядки_в_Англии_в_августе_2011_года (дата обращения 14.01.2021).

20. Массовые беспорядки в Швеции 2013 года. Википедия - свободная энциклопедия. URL: https://ru.wikipedia.org/wiki/Macсовые_беспорядки_в_Швеции_2013_ года (дата обращения 14.01.2021).

21. Протесты после гибели Джорджа Флойда. Википедия - свободная энциклопедия. URL: https://ru.wikipedia.org/wiki/Протесты_после_гибели_Джорджа_Флойда (дата обращения 14.01.2021).

22. Тимошенко B.I. Договірна теорія походження держави. Юридична енциклопедія: в 6 т. Редкол.: Ю.С. Шемшученко та ін. Київ: Видавництво «Українська енциклопедія» ім. М.П. Бажана, 1998. Т. 2: Д-Й. URL: https://leksika.com.ua/17190303/legal/ dogovirna_teoriya_pohodzhennya_derzhavi (дата звернення 16.06.2021р.). 
23. Гоббс Т. Избранные произведения: в 2 т. Москва: Мысль, 1964.

24. Кормич А.І. Історія вчень про державу і право: навчальний посібник. Київ: Правова єдність, 2009. 312 с.

25. Столыпин П.А. Декларація Правительства по аграрному вопросу. Засъданіе Государственной Думы 10.IV.1907 г. Сборникъ речъй Петра Аркадьевича Столыпина, произнесенныхъ въ засъданіяхъ Государственнаго Совъта и Государственной Думы (1906-1911). Санктъ-Петербургъ: Изданіе В.В. Логачева, 1911. 131 с.

Кононенко Ю. С., Джолос С. В. Держава і революції. Частина III. Основні ідейно-теоретичні засади революцій Нового часу і сучасності

Стаття присвячена виявленню основних ідейно-теоретичних засад революцій Нового часу і сучасності.

З'ясовано, що порівняно з давніми революціями, основні прогресивні ідеї яких були розроблені плеядою видатних мислителів та відображені у програмних документах, що мали епохальне значення, революції сьогодення відрізняються ідейною схематичністю і примітивізмом, не мають істотного філософського й теоретичного підгрунтя, серйозних програмних документів і цілісного плану реформ тощо.

Виявлено, що основними ідеями сучасних революцій є зміна зовнішньополітичного вектору та повалення «поганого» старого правителя для передання влади «хорошому» новому. Водночас революціонерами не беруться до уваги ті факти, що інтереси «іноземних партнерів» можуть суперечити національним інтересам їхньої батьківщини, а будь-який міжнародний договір, укладений за підсумками революції, може бути легко денонсований. Революціонери забувають, що в умовах республіки нова влада встановлюється лише на кілька років, до наступних виборів і що в умовах поділу влади та розгалуженого апарату держави із сотнями тисяч чиновників президент не є самодержцем, який має достатню владу й можливості для забезпечення добробуту. Крім того, гіпотетичні прогресивні реформи неодмінно наштовхнуться на запеклий опір клептократії, тож за жодних обставин новий «хороший» демократичний правитель не зможе правити довго та ефективно. Отже, революція не є панацеєю для вирішення суспільно-політичних проблем. Революціонери не розуміють, що повалення «поганої» старої влади не тотожне утвердженню «хорошої» нової влади, і що маси є лише знаряддям боротьби клептократичних олігархічно-політичних еліт. Зроблено висновок, що революція - це політична авантюра, яка шкодить насамперед самому народові.

Зроблено висновок, що революції сучасності насправді не є революціями, оскільки вони не призводять до глибоких якісних перетворень, кардинальної зміни соціально-економічної моделі, політичного режиму, системи, ідеології тощо. Вказано, що відкидання формаційного підходу створює ситуацію невизначеності щодо наступної суспільно-економічної формації та мети, якої має прагнути сучасна революційна ідея.

Виявлено, що ідейний вакуум та відсутність грунтовних теоретичних підвалин, притаманних сучасним революціям, означають їхню принципову непридатність до прогресивних зрушень і вирішення проблем суспільства.

Ключові слова: революція, ідея, мислителі, програмні документи, зміна суспільно-економічної формації, сучасна революція, ідейний примітивізм, повалення влади, зміна зовнішньополітичного вектору, деструктивний початок.

Кононенко Ю. С., Джолос С. В. Государство и революции. Часть ІІІ. Ключевые идейно-теоретические основы революций Нового времени и современности

Статья посвящена выявлению ключевых идейно-теоретических основ революций Нового времени и современности.

Определено, что в сравнении со старинными революциями, основные идеи которых были разработаны плеядой выдающихся мыслителей и отображены в программных документах, имевших эпохальное значение, революции современности отличаются идейной 
схематичностью и примитивизмом, не имеют существенного философского и теоретического основания, серьезных программных документов и целостного плана реформ.

Установлено, что основными идеями современных революций являются смена внешнеполитического вектора и свержение «плохого» старого правителя для передачи власти «хорошему» новому. При этом революционерами не принимаются во внимание те факты, что интересы «иностранных партнеров» могут противоречить национальным интересам их родины, а любой международный договор, заключенный по итогам революции, может быть легко денонсирован. Революционеры забывают, что в условиях республики новая власть устанавливается лишь на несколько лет, до следующих выборов, и что в условиях разделения властей и разветвленного аппарата государства с сотнями тысяч чиновников президент не является самодержцем, имеющим достаточную власть и возможности для обеспечения благоденствия. Также очевидно, что гипотетические прогрессивные реформы непременно натолкнутся на ожесточенное сопротивление клептократии, и в любом случае новый «хороший» демократический правитель не сможет править долго и эффективно. Таким образом, революция не является панацеей для решения общественно-политических проблем. Революционеры не понимают, что свержение «плохой» старой власти не тождественно утверждению «хорошей» новой, и что массы являются лишь инструментом борьбы клептократических олигархическо-политических элит. Сделан вывод о том, что революция - это политическая авантюра, которая вредит в первую очередь самому народу.

Сделан вывод о том, что революции современности на самом деле не являются революциями, поскольку они не приводят к глубоким качественным преобразованиям, кардинальному изменению социально-экономической модели, политического режима, системы, идеологии и т.п. Указано, что отказ от формационного подхода создает ситуацию неопределенности в отношении следующей общественно-экономической формации и цели, к которой должна стремиться современная революционная идея.

Выявлено, что идейный вакуум и отсутствие фундаментальных теоретических основ, характерные для современных революций, означают их принципиальную непригодность для прогрессивных изменений и решения проблем общества.

Ключевые слова: революция, идея, мыслители, программные документы, изменение общественно-экономической формации, современная революция, идейный примитивизм, свержение власти, изменение внешнеполитического вектора, деструктивное начало.

Kononenko Yu. S., Dzholos S. V. The State and Revolutions. Part III. The fundamental ideological and theoretical grounds of the revolutions of the Modern age and of the contemporary period

The article is devoted to the investigation of the fundamental ideological and theoretical grounds of the revolutions of the Modern age and of the contemporary period.

It was found that in the comparison to the old revolutions, which had the ideas, developed by the wise philosophers and written in the great programmatic documents, the revolutions of the contemporary period are characterized by the ideological primitivism, lack of the philosophic and theoretical basis, absence of the serious programmatic documents and holistic plans of the reforms, etc.

It was found that the main ideas of modern revolutions are to change the foreign policy vector and to overthrow the «bad» old ruler to transfer the power to the «good» new one. At the same time, rebels do not take into account that the interests of «foreign partners» may contradict the national interests of their motherland, and that any international treaty, concluded as a result of a revolution, may be easily denounced. The rebels forget that in a republic the new government is established only for a few years, until the next elections, and that the separation of powers and a branched state apparatus with hundreds of thousands of officials make the situation, when the president has not the power of the absolute monarch and sufficient competence to lead his country to the prosperity. Also, hypothetical 
progressive reforms will meet the fierce resistance from the kleptocracy. So, in any case, a new «good» democratic ruler will not be able to govern the state effectively and for a long time. So, revolution is not a panacea, which may solve social and political problems. The rebels do not understand that the overthrow of the «bad» old government is not the same as the establishment of a «good» new one, and that the masses are only an instrument of the struggle of kleptocratic oligarchic-political elites. It is concluded that the revolution is a political adventure that harms, first of all, the people themselves.

The authors came to the conclusion that the revolutions of the contemporary period are not really revolutions, because they do not lead to profound qualitative changes, such as radical change of the socio-economic model, political regime, system, ideology, etc. It is pointed out that the disregard of the formational approach creates a situation of uncertainty in the question of the next socio-economic formation and the goal of the modern revolutionary idea.

It was found that the ideological vacuum and lack of the serious theoretical basis, which are peculiar to the revolutions of the modernity, show their principle unsuitability for progressive changes and solving of the social problems.

Key words: revolution, idea, philosophers, programmatic documents, change of the socio-economic formation, modern revolution, ideological primitivism, overthrow of power, change of the foreign policy vector, destructive source. 